\title{
Editorial
}

\section{Novos olhares para a longevidade: alguns questionamentos}

O envelhecimento populacional é fato em nosso país e no mundo todo, trazendo desafios importantes a serem superados nos vários setores da sociedade, sejam eles relativos às áreas da saúde, jurídica, social, econômica e as demais que permeiam este processo. Há muitas questões a serem discutidas, estudadas e resolvidas. Mas, como estamos envelhecendo? 0 que esperamos dos serviços prestados aos idosos?

Considerando as boas experiências, a atenção à saúde do idoso tem se baseado em modelo descoordenado, com soluções pontuais e medicalização, estrutura centrada em hospitais, atendimento nem sempre baseado na interdisciplinaridade, além da escassez de recursos. Precisamos nos preparar para a diversidade de abordagens, considerando gêneros, idosos que vivem sozinhos e que cuidam de idosos, quilombolas, sertanejos, indígenas, insulares, imigrantes.

0 que esperar daqueles que tiveram pouco ou nenhum acesso à educação formal? Questões como a polifarmácia, a precariedade da saúde bucal, o aumento dos casos de sobrepeso e obesidade, doenças cardiovasculares, diabetes e neoplasias, mas também de desnutrição e sarcopenia, demências, fragilidade, incapacidade e dependência pioram a qualidade de vida dos idosos e necessitam de recursos educativos para adesão terapêutica e da assistência. Precisamos nos preparar para a diversidade deste grupo populacional.

E o que dizer das relações intergeracionais e intrageracionais tão importantes nas famílias atuais e para a qualidade de vida do idoso e seus pares? Será que estes aspectos, além da sexualidade, comunicação e lazer têm sido explorados no cotidiano dos serviços de atenção ao idoso?

A saúde dos idosos está contemplada nas várias políticas do Brasil? A rede de proteção social e os conselhos de idosos estão preparados para atuarem? Como se mobilizam as organizações governamentais? As instituições de longa permanência para idosos (ILPI`s) estão organizadas para a recepção de sua clientela? Os cuidadores formais e informais estão capacitados e também recebendo cuidados? Precisamos de mais atenção domiciliar e também cuidados paliativos, equipes com diversos saberes e alternativos para atender ao idoso e à família e a diversidade que se apresenta, além de resolutividade das várias questões pendentes.

A insuficiência dos saberes isolados torna urgente as adequações dos currículos dos cursos superiores para atender as demandas, apontando para a necessidade de inclusão das disciplinas de geriatria e gerontologia.

Estamos preparados para o envelhecimento da população?

Boa Leitura!

Profa. Dra. Estefânia Maria Soares Pereira Departamento de Nutrição - UFTM/Brasil Membro da Diretoria Executiva da REFACS 